\title{
ENZYMATIC DETERMINATION OF STARCH IN DOCE DE LEITE USING DIALYSIS ${ }^{1}$
}

\author{
Ivo Motim DEMIATE ${ }^{2, *}$, Francisco Enéias $\mathrm{KONKEL}^{3}$, Ricardo Alexandre PEDROSO ${ }^{3}$
}

\begin{abstract}
SUMMARY
The importance of starch for the food industry makes it necessary to develop new, fast, economic and accurate methodologies for its quantification. In the present paper starch hydrolysis using commercial enzymes of industrial grade are studied aiming to develop an easy and cheap analysis, available to a greater number of industries and technicians. The proposed method is simple, divided in a first step where soluble sugars are eliminated from the samples by using dialysis, followed by starch hydrolysis of the retained fraction with a thermoresistent bacterial alfa-amylase (Termamyl 120L $\AA$ ) and an amyloglucosidase (AMG $300 \mathrm{~L} \circledast$ ). The hydrolysis conditions were those suggested by the enzyme producer. After the hydrolysis step the material was dialysed again for the extraction of glucose that was quantified by the glucose-oxidase colorimetric reactant. The results allowed the construction of calibration equations for starch determination on the analyzed samples. These samples were produced on a laboratory scale and native and acid-modified corn starches were added in known concentrations. By considering the final dilutions employed for glucose determination on the samples, it was possible to confirm that they were identical to that of the glucose-oxidase reactant calibration.
\end{abstract}

Keywords: starch quantification; doce de leite; dialysis.

\section{RESUMO}

DETERMINAÇÃO ENZIMÁTICA DE AMIDO EM DOCE DE LEITE COM USO DE DIÁLISE. A ampla utilização de amido pelas indústrias de alimentos faz com que haja necessidade de desenvolvimento de novas metodologias, mais rápidas, econômicas e precisas para a sua quantificação. Conforme proposto neste trabalho, a hidrólise utilizando enzimas comercias de uso industrial pode vir a agilizar e baratear os custos da análise em laboratórios e indústrias, com resultados confiáveis. A metodologia proposta é simples envolvendo, em uma primeira etapa a eliminação dos açúcares solúveis das amostras por diálise seguida da hidrólise, do material retido com uma alfa-amilase bacteriana termorresistente (Termamyl 120L $\AA$ ) e uma amiloglucosidade (AMG 300L $\AA$ ). A hidrólise foi conduzida seguindo-se as recomendações do fabricante das enzimas. Após a etapa de hidrólise, o material foi dialiasado novamente para extração da glucose que foi determinada enzimaticamente com uso de reativo glucose-oxidase. Os resultados possibilitaram a construção de curvas de calibração para a quantificação de amido nas amostras estudadas. As amostras foram produzidas no laboratório e adicionadas de quantidades conhecidas de amido de milho (nativo e ácido-modificado). Foi possível confirmar que as equações obtidas para a determina-

\footnotetext{
${ }_{1}^{1}$ Recebido para publicação em 20/04/01. Aceito para publicação em 24/08/01.

2 Universidade Estadual de Ponta Grossa, Departamento de Zootecnia e Tecnologia de Alimentos. Praça Santos Andrade, s/n, Ponta Grossa PR. CEP 84010-330. E-mail: demiate@interponta.com.br (corresponding author).

${ }^{3}$ Acadêmicos do Curso de Graduação em Engenharia de Alimentos da UEPG, bolsistas PIBIC/CNPq/UEPG.

${ }^{*}$ A quem a correspondência deve ser enviada.
}

ção de amido eram idênticas àquelas do reativo glucose-oxidase, considerando-se as diluições.

Palavras-chave: quantificação de amido; doce de leite; diálise.

\section{1 - INTRODUCTION}

Starch is a food ingredient widely used mainly for its thickening and stabilizing properties [2,13]. The use of starch in the production of doce de leite is allowed but there is a legal limit of adding a maximum of $0.5 \mathrm{~g} / 100 \mathrm{~mL}$ to the milk [3]. The main function of the starch in this product is to improve the consistency as well as the final yield. There are some producers that use this cheap raw material in higher amounts than that allowed. Considering that doce de leite is a regional product and that there is relatively little research on its quality, this kind of fraud is present in some Brazilian commercial samples [7].

In many cases starch quantification is not made directly. It is calculated as the difference between the dry matter and all the other components (proteins, lipids, sugars, fibers and minerals). In doce de leite production besides starch other carbohydrates are employed, generally sucrose and glucose. As milk is the principal ingredient, lactose will also be present. As starch determination is done after its total hydrolysis to glucose, all these added sugars must be eliminated from the samples. The elimination of sugars from food samples like this one may be done by dialysis [4, 5, 12].

The enzymatic methods for starch determination in foods involve the utilization of purified amylases [1, 9, $10,14,15,16,17]$. Gelatinized starch is hydrolyzed to glucose by amiloglucosidase that is generally associated with an alfa-amylase. The concentration of glucose is determined by an enzymatic method (glucose-oxidase, for example) and corrected to starch by a 0.9 factor $[4$, $5,8,10]$.

The objective of the present paper is to determine starch by an enzymatic method in doce de leite samples produced on a laboratory scale and obtaining a calibration curve for future application on commercial samples. Commercial enzymes of industrial grade will be employed aiming to simplify and decrease the analysis cost, making this methodology available to a greater number of producers and technicians.

\section{2 - MATERIAL AND METHODS}

\section{1 - Material}

The samples were produced in the laboratory by cooking raw milk with sucrose, glucose, sodium 
bicarbonate and different amounts of native and acid modified corn starch $\left(\right.$ Candymi ${ }^{\circledR}$, Corn Products Brasil, Balsa Nova, PR, Brasil). Industrial grade amylases (Termamyl 120L ${ }^{\circledR}$ and AMG 300L ${ }^{\circledR}$, Novozymes, Araucária, PR, Brasil) were used for starch hydrolysis.

\section{2 - Methods}

The doce de leite process used $500 \mathrm{~g}$ of raw milk, $100 \mathrm{~g}$ of sucrose, $5 \mathrm{~g}$ of glucose, $0.5 \mathrm{~g}$ of sodium bicarbonate and native corn starch were used in the concentrations $0.0,0.41,0.81,1.24,1.65,2.06$ and $2.5 \%$, calculated over the total mass of ingredients before cooking started. Other samples were produced with the same concentrations of the ingredients described above and acid modified corn starch in the concentrations of $0.0,0.5,1.0,1.5,2.0,2.5$ and $3.0 \%$, calculated by the same manner. The cooking time, on a direct low fire and with constant stirring, was standardized at $1 \mathrm{~h} 20 \mathrm{~min}$ in order to have similar yields. The yields were measured gravimetricaly as the ratio between the final weight of the product and the initial weight of the mixture of ingredients before cooking.

The moisture of the samples was determined by oven drying at $105^{\circ} \mathrm{C}$ [11], and the final contents of starch were re-calculated considering the dry matter (DM) of the product.

For the starch determination, 200mg of moist samples were dissolved in around three milliliters of deionized water. This volume was quantitatively transferred to dialysis sacks (MW 12, 000, cod. 250-7U, Sigma Chemical Co., St. Louis, MO, USA) and were put in a water bath at $45^{\circ} \mathrm{C}$, and the water was changed during four hours for complete removal of the soluble sugars. The dialyzed samples were transferred to hermetic tubes, the $\mathrm{pH}$ adjusted to 5.5-6.0 and 40ppm of $\mathrm{Ca}^{++}$(calcium chloride solution) and $10 \mu \mathrm{L}$ of the enzyme Termamyl $120 \mathrm{~L}^{\circledR}$ (Novozymes, Araucária, PR, Brasil) were added. This suspension was kept in an ebullition water bath for $15 \mathrm{~min}$. After cooling to room temperature, the $\mathrm{pH}$ was corrected to 4.5 and $20 \mu \mathrm{L}$ of the enzyme AMG $300 \mathrm{~L}^{\circledR}$ (Novozymes, Araucária, $\mathrm{PR}$, Brasil) were added. The hermetic tubes were maintained in a water bath at $60^{\circ} \mathrm{C}$ for $24 \mathrm{~h}$ until complete hydrolysis of the starch.

After hydrolysis the samples were quantitatively transferred from the hermetic tubes to beakers, the weight adjusted to $10 \mathrm{~g}$ with deionized water and transferred again to dialysis sacks that were put in Erlenmeyer flasks containing $90 \mathrm{~g}$ of deionized water. After four hours at $45^{\circ} \mathrm{C}$ with agitation, aliquots were collected from each flask and diluted five times. Glucose was quantified in these diluted aliquots by employing the glucose oxidase (GOD) colorimetric method [6]. A standard curve was constructed considering the absorbance of the diluted samples (2,500 times, in moist basis) and their starch contents on a dry basis. For each sample two determinations of starch were made and the glucose was quantified in triplicate in order to have reliable results.

When a glucose-oxidase reactant is prepared it is necessary to construct a calibration curve with known glucose concentrations $(0-70 \mu \mathrm{g} / \mathrm{mL}$, for example). If a new reactant is prepared it is essential that a new calibration curve is constructed due to small variations in the values (both of the reactant and of the glucose solutions). In this paper two different glucose-oxidase reactants were used and their calibration curves varied slightly. For the doce de leite samples produced with the addition of native corn starch the GOD reactant had a standard curve described by the equation $y=0.0107 x$ $\left(r^{2}=0.9988, n=12\right)$ whereas for the samples produced with the acid modified corn starch the equation was $y=0.0103 x\left(r^{2}=0.9997, n=12\right)$.

\section{3 - RESULTS AND DISCUSSION}

The moisture and the yields of the samples produced with different concentrations of corn starches are shown in Table 1.

TABLE 1. Moisture content, yield (in moist basis) and final starch content of the doce de leite samples.

\begin{tabular}{lcccccccccccccc}
\hline \multicolumn{1}{c}{ Initial native starch \% } & \multicolumn{1}{c}{ Initial modified starch \% } \\
\hline & 0.0 & 0.41 & 0.81 & 1.24 & 1.65 & 2.06 & 2.5 & 0.0 & 0.5 & 1.0 & 1.5 & 2.0 & 2.5 & 3.0 \\
\hline Moisture \% & 31.1 & 36.4 & 38.4 & 25.7 & 36.6 & 25.5 & 30.0 & 18.0 & 26.8 & 23.6 & 33.1 & 32.4 & 32.9 & 33.9 \\
Yield \% & 42.2 & 45.0 & 46.0 & 47.0 & 45.0 & 42.0 & 44.3 & 33.0 & 37.0 & 36.6 & 41.7 & 37.5 & 42.7 & 43.6 \\
Final starch\% (DM) & 0.0 & 1.4 & 2.84 & 3.51 & 5.69 & 6.45 & 7.87 & 0.0 & 1.84 & 3.54 & 5.30 & 7.73 & 8.51 & 10.11
\end{tabular}

The dialyzed, amylase-hydrolyzed and conveniently diluted doce de leite samples were evaluated with the above described colorimetric method and the results used for the construction of calibration curves with the final starch contents. Figures 1 and 2 show these calibration curves.

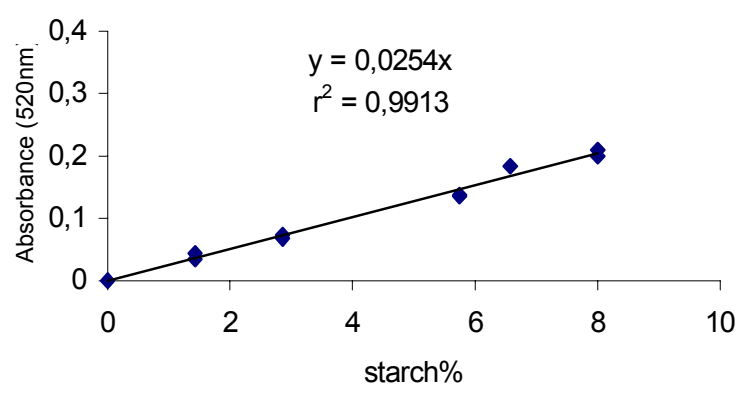

FIGURE 1. Calibration curve of the samples produced with native corn starch $(n=10)$.

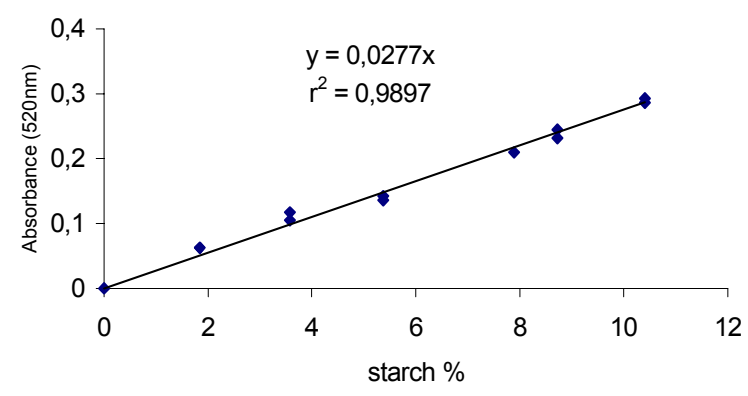

FIGURE 2. Calibration curve of the samples produced with acid modified corn starch $(n=12)$. 
The regression between absorbance and the amount of native starch present on the dry matter of the produced samples resulted in the equation $y=0.0254 \times\left(r^{2}=0.9887\right)$. For the samples produced with the acid modified starch the equation was $y=0.0276 x\left(r^{2}=0.9894\right)$. The equations were different due to the utilization of different GOD reactants as described earlier and also because of some differences in the starch concentrations of the samples. Considering the moisture of the samples it is possible to find an average value that allows the calculation of final dilutions used for the calibration curves construction. With these values and calculations we concluded that the equations shown in Figures 1 and 2 were the same as that of the GOD calibration, which shows that the method is reliable for the quantification of starch in samples containing starch in the studied range. For obtaining the starch calibration curve from the GOD equation, the following equation may be used:

$y=(1 / x) / z$

where:

$y-$ angular coefficient of the starch calibration equation

$\mathrm{x}$ - dilution

$z$ - angular coefficient of the GOD reactant calibration equation

The final average dilutions were calculated from the data of Table 1 and were 3505 times for the samples produced with modified starch and 3674 times for the ones produced with native starch.

The dialysis used for the elimination of undesirable substances present in the samples was adequate for the objectives of this study. The first one was made for eliminating soluble sugars (mainly sucrose, lactose and glucose) and was efficient because the sample containing $0.0 \%$ of starch resulted in an absorbance equal to the blank, which had no sample but water, $\mathrm{Ca}^{++}$, and the enzymes. The second dialysis was done in order to separate the hydrolyzed starch (glucose solution) from the other constituents of the samples (especially proteins). The results were reliable because, based on the added starch, the found glucose concentrations were those expected.

\section{4 - CONCLUSIONS}

- The proposed methodology that involved dialysis, enzymatic hydrolysis and glucose colorimetric determination allowed the quantification of starch in doce de leite samples;

- The production of the doce de leite samples with known concentrations of starch, from absence to $10.11 \%$ (DM) made it possible to construct calibration curves that will be employed for the analysis of starch on commercial samples;

- The calibration equations for starch were similar to that of the GOD reactant and showed the reliability of the developed method;
- The proposed method has the advantage of using commercial enzymes of industrial grade, which are cheaper than the purified ones commonly employed on other studies.

\section{5 - REFERENCES}

[1] ARÊAS, J. A. G.; LAJOLO, F. M.. Determinação enzimática específica de amido, glicose, frutose e sacarose em bananas preclimatéricas e climatéricas. Anais de Farmácia e Química de São Paulo, v. 20, n. 1/2, p. 307-318, jan./dez. 1980.

[2] BOURSIER, B. Applications alimentaires des amidons modifiés. Industries Alimentaires et Agricoles, p. 2-11, Septembre 1994.

[3] BRASIL. Ministério da Agricultura e do Abastecimento, Secretaria de Defesa Agropecuária, Departamento de Inspeção de Produtos de Origem Animal. Portaria n. 354, de 4 de setembro de 1997. Disponível em: http:// www.agricultura.gov.br/das/dipoa/port354.html Acesso em: 16 nov. 2000.

[4] CHATEL, S.; VOIRIN, A.; LUCIANI, A.; ARTAUD, J. Starch identification and determination in sweetened fruit preparations. Journal of Agricultural and Food Chemistry, v. 44, n. 2, p. 502-506, 1996.

[5] CHATEL, S.; VOIRIN, A.; ARTAUD, J. Starch identification and determination in sweetened fruit preparations. 2 . Optimization of dialysis and gelatinization steps, infrared identification of starch chemical modifications. Journal of Agricultural and Food Chemistry, v. 45, n. 2, p. 425430, 1997.

[6] DAHLQUIST, A. Determination of maltase and isomaltase activities with a glucose oxidase reagent. Biochemical Journal., London, n. 80, p. 547-51, 1961.

[7] DEMIATE, I.M.; KONKEL, F.E.; PEDROSO, R.A. Avaliação da qualidade de amostras comerciais de doce de leite pastoso - Composição química. Ciênc. e Tecnol. de Aliment., 2001. (no prelo)

[8] EMNEUS, J.; NILSSON, G.; GORTON, L. A flow injection system for the determination of starch from different origins with immobilized alpha-amylase and amyloglucosidase reactors. Starch/Stärke, v. 45, n. 8, p. 264-270, 1993.

[9] GARCIA, E.; CORDENUNSI, B. R.; LAJOLO, F. M.. Determinação de amido em embutidos: comparação entre o método de Fehling e método enzimático. Ciênc. e Tecnol. de Aliment., v. 5, n. 1, p. 39-46, 1985.

[10] HOLM, J.; BJÖRCK, I.; DREWS, A.; ASP, N.-G.. A rapid method for the analysis of starch. Starch/Stärke, v. 38, n. 7, p. 224-226, 1986.

[11] IAL - Normas Analíticas do Instituto Adolfo Lutz. $3^{a}$ ed., São Paulo: Instituto Adolfo Lutz, 1985. 533p. (Volume 1, Métodos Químicos e Físicos para Análise de Alimentos).

[12] MISTRY, V. V.; HASSAN, N. H.; BAER, J.R.. Spectrophotometric method for measurement of lactose in milk and milk products by using dialysis. Journal of Association Of Official Agricultural Chemists., v. 72, n. 6, p. 877-880, 1989.

[13] MOORE, C. O.; TUSCHHOFF, J. V.; HASTINGS, C. W.; SCHANEFELT, R. V.. Applications of starches in foods. In: WHISTLER, R. L.; BEMILLER, J. N.; PASCHALL, E. F. (eds.). Starch: Chemistry and Tecnology, San Diego: Academic Press, $2^{\text {nd }}$ ed., 1984. p. 575-291.

[14] MORALES, M. D.; ESCARPA, A.; GONZÁLEZ, M. C.. Simultaneous determination of resistant and digestible starch in foods and food products. Starch/Stärke, v. 49, n. 11, p. 448-453, 1997. 
[15] MOTA, R. V. da; LAJOLO, F. M.; CORDENUNSI, B. R.. Composição em carboidratos de alguns cultivares de banana (Musa spp.) durante o amadurecimento. Ciênc. e Tecnol. de Aliment., v. 17, n. 2, p. 94-97, 1997.

[16] NEBESNY, E.; ROSICKA, J.; PIERZGALSKI, T. Enzymatic hydrolysis of wheat starch into glucose. Starch/Stärke, v. 50, n. 8 , p. 337-341, 1998

[17] SCHWANK, U. Quantitative Stärkebestimmung in Milchproducten und Fruchtzubereitungen. DMZ Lebensmittelindustrie und Milchwirtschaft, v. 16, p. 760-765, 1995.

\section{6 - ACKNOWLEDGEMENTS}

The authors are grateful to the Universidade Estadual de Ponta Grossa and to the CNPq (Conselho Nacional de Desenvolvimento Científico e Tecnológico) that provided scholarships (PIBIC/CNPq/UEPG Program), to Novozymes for supplying the enzymes and to Corn Products Brasil for supplying the modified starch. 